ISSN 1678-3921

Journal homepage: www.embrapa.br/pab

For manuscript submission and journal contents, access: www.scielo.br/pab

\section{Biological solubilization of phosphate rock by solid- state cultivation to produce eco-friendly fertilizers}

\begin{abstract}
The objective of this work was to evaluate the solubilization of phosphorus from a phosphate rock by Aspergillus niger, under solidstate cultivation (SSC) in sugarcane (Saccharum officinarum) bagasse, by maximizing the efficiency of citric acid production. The phosphate rock (IPR) chosen for the study is a type of igneous rock with a very low phosphorus solubility, obtained from the Itafós company, in Arraias, in the state of Tocantins, Brazil. The rotatable central composite design (RCCD) was used as a statistical tool to evaluate the effect of the concentrations of the carbon source (sucrose) and of the IPR on the SSC medium as a strategy to improve P solubilization. In the process without the IPR, there was a citric acid production of up to $300 \mathrm{~g}$ per kilogram of substrate. The experiments in the RCCD showed that the addition of the IPR affected citric acid production, with values of solubilized P ranging from 1.44 to $2.72 \mathrm{~g}$ per kilogram of substrate and of solubilized P yield from 12.96 to $48.94 \%$. The analysis of the solubilized P/ sucrose ratio showed favorable conditions for $\mathrm{P}$ solubilization and citric acid production. The obtained solubilized $\mathrm{P}$ values are promising considering that the IPR has a very low solubilization, with only $8.6 \% \mathrm{P}_{2} \mathrm{O}_{5}$. Overall, these findings could contribute to the development of biotechnological processes for producing eco-friendly phosphate fertilizers, as an alternative for a more sustainable agriculture.
\end{abstract}

Index terms: Aspergillus niger, phosphate mineral, phosphate rock, solidstate cultivation, sugarcane bagasse.

\section{Solubilização biológica de rocha fosfática por cultivo em estado sólido para produção de fertilizantes ecológicos}

Resumo - O objetivo deste trabalho foi avaliar a solubilização de fósforo de rocha fosfática por Aspergillus niger, em cultivo em estado sólido (CES) em bagaço de cana-de-açúcar (Saccharum officinarum), por meio da maximização da eficiência de produção de ácido cítrico. A rocha fosfática (IPR) escolhida para o estudo é um tipo de rocha ígnea com solubilização de fósforo muito baixa, obtida da empresa Itafós, em Arraias, no estado do Tocantins. Utilizou-se o delineamento composto central rotacional (DCCR) como ferramenta estatística para avaliar o efeito das concentrações da fonte de carbono (sacarose) e da IPR no meio para CES como estratégia para melhorar a solubilização de P. Para o processo sem a IPR, houve produção de ácido cítrico de até $300 \mathrm{~g}$ por quilograma de substrato. Os experimentos em DCCR mostraram que a adição da IPR afetou a produção de ácido cítrico, com valores de P solubilizado de 1,44 a 2,72 g por quilograma de substrato 
e rendimento de P solubilizado de 12,96 a 48,94\%. Além disso, a análise da razão P solubilizado/sacarose mostrou condições favoráveis para solubilização de $\mathrm{P}$ e produção de ácido cítrico. Os valores de P solubilizado são promissores, ao se considerar que a IPR apresenta baixa solubilização, com apenas 8,6\% de $\mathrm{P}_{2} \mathrm{O}_{5}$. No geral, esses resultados podem contribuir para o desenvolvimento de processos biotecnológicos, para a produção de fertilizantes fosfatados ambientalmente favoráveis, como alternativa para uma agricultura mais sustentável.

Termos para indexação: Aspergillus niger, fosfato mineral, rocha fosfática, cultivo em estado sólido, bagaço de canade-açúcar.

\section{Introduction}

Phosphorus is an important nutrient for plants and is usually supplied in the form of soluble fertilizers produced by chemical treatments of phosphate rock (Vassileva et al., 2010). Different technologies have been developed to process this type of rock and to obtain new fertilizer products for a more sustainable agriculture (Everaert et al., 2016; Benicio et al., 2017). A potential alternative for obtaining soluble $P$ fertilizers is the use of P-solubilizing microorganisms (PSMs) to promote the solubilization of phosphate rock by biotechnological processes (Vassileva et al., 2010; Mendes et al., 2015; Klaic et al., 2018).

The P-solubilizing activity of PSMs is determined mainly by their ability to produce and release metabolites such as organic acids that chelate cations (mainly calcium) bound to phosphate (Kpomblekou-a \& Tabatabai, 1994; Illmer \& Schinner, 1995; Mendes et al., 2014). Among these organic acids, citric acid has been reported to promote a solubilization of phosphate rock comparable to the one achieved by the conventionally used sulfuric acid (Schneider et al., 2010; Liu et al., 2012; Lazo et al., 2017). However, the biological $\mathrm{P}$ solubilization is affected by the concentration of citric acid in the medium (Schneider et al., 2010), with Aspergillus niger being a potential PSM due to its high rates of growth and organic acid production (Papagianni, 2007). Although most of the A. niger strains are good producers of citric acid, some may be more efficient than others (Mendes et al., 2014; Li et al., 2016; Klaic et al., 2017). Therefore, the selection of a fungal strain and of cultivation conditions are crucial for the development of a process for the biological P solubilization of phosphate rock.
Microbes may be cultivated under liquid aerated suspensions, known as submerged cultivation ( $\mathrm{SmC})$, or using a solid medium, i.e., solid-state cultivation (SSC). Although $\mathrm{SmC}$ has been widely used industrially, SSC can be particularly advantageous for the cultivation of filamentous fungi, because it simulates the natural habitat of these microorganisms (Farinas, 2015). From the environmental perspective, an important advantage of SSC is the ability to use agro-industrial wastes as low-cost sources of carbon. A potential substrate for SSC is sugarcane (Saccharum officinarum L.) bagasse due to its properties and availability, being used for the production of valueadded bio-products, such as enzymes and organic acids (Soccol et al., 2008; Rodríguez-Zúñiga et al., 2011; Sharan et al., 2015; Dezam et al., 2017). Therefore, studies focusing on the development of bioprocess strategies for the solubilization of phosphate rock using sugarcane bagasse as a substrate for SSC could potentially contribute to obtain eco-friendly fertilizers for a more sustainable agriculture.

The objective of this work was to evaluate the solubilization of phosphorus from a phosphate rock by Aspergillus niger, under solid-state cultivation in sugarcane bagasse, by maximizing the efficiency of citric acid production.

\section{Materials and Methods}

The phosphate rock used for the assessment of $\mathrm{P}$ solubilization is of the igneous type and presents a very low P solubility. It was donated by the Itafós company (Arraias, TO, Brazil), being called Itafós phosphate rock (IPR).

As PSMs, the three following fungal strains were subjected to a preliminary screening to determine their capacity for organic acid production: A. niger C, obtained from Embrapa Agroindústria de Alimentos, located in Rio de Janeiro, in the state of Rio de Janeiro, Brazil; and A. niger 763 and Penicillium pinophilum F14, from the collection of Embrapa Milho e Sorgo, located in Sete Lagoas, in the state of Minas Gerais, also Brazil. The $A$. niger ATCC 9142 strain was used as a reference for citric acid production (Xie \& West, 2009). Spore suspensions were kept at $-18^{\circ} \mathrm{C}$ and activated by incubation on Petri dishes containing potato dextrose agar, for 96 hours, at $30^{\circ} \mathrm{C}$. Spore concentrations were determined in a Neubauer chamber. 
The used substrate consisted of: sugarcane bagasse untreated and pretreated by steam explosion, which was donated by a local mill, called Usina Nardini (Vista Alegre do Alto, SP, Brazil); and wheat bran, acquired from Claro Agropecuária (São Carlos, SP, Brazil). The sugarcane bagasse samples were milled and sieved, and the selected particle size was $1.0 \mathrm{~mm} \leq$ diameter $\geq 2.0 \mathrm{~mm}$.

Before the solubilization experiments, the IPR was dried at $110^{\circ} \mathrm{C}$ for 48 hours to reduce humidity content and was ground for $10 \mathrm{~min}$ in the CT-241 orbital mill (Servitech, Tubarão, SC, Brazil), consisting of a porcelain jar and alumina balls (Plotegher \& Ribeiro, 2016; Klaic et al., 2017). The phosphate rock was then stored in dry boxes at room temperature for further characterizations and use in the experiments. The IPR was characterized by X-ray fluorescence, using the lithium tetraborate fusion technique to analyze the ten most commonly found oxides in the ores. The morphology of the IPR samples was observed by field emission gun scanning electron microscopy (FEGSEM), with the JSM-6701F FEG microscope (JEOL, Akishima, Tokyo, Japan). Images were captured using an acceleration voltage of $2 \mathrm{kV}$ and secondary electron detection. Particle size was determined by dynamic light scattering analyses with the high-performance particle size analyzer ZetaSizer (Malvern Panalytical Ltd, Malvern, UK). The total surface area of the samples was measured by isothermal nitrogen adsorption, using the ASAP 2020 instrument (Micromeritics, Norcross, GA, USA) and the five-point Brunauer-Emmett-Teller method.

The SSC experiments were carried out in $250-\mathrm{mL}$ Erlenmeyer flasks using the untreated and pretreated sugarcane bagasse and wheat bran as a substrate in a 3:1 proportion (Dezam et al., 2017). The total mass used in each experiment was $3.0 \mathrm{~g}$ dry biomass. The initial moisture content was adjusted to $75 \%(\mathrm{w} / \mathrm{v})$ using the nutrient solution adapted from Kumar et al. (2003), consisting of (wt $\%$ ): $20 \%$ sucrose, $0.25 \%$ $\left(\mathrm{NH}_{4}\right)_{2} \mathrm{SO}_{4}, 0.1 \% \mathrm{KH}_{2} \mathrm{PO}_{4}, 0.025 \% \mathrm{MgSO}_{4} 7 \mathrm{H}_{2} \mathrm{O}$, and $0.004 \% \mathrm{CuSO}_{4}$, at $\mathrm{pH} 6$. The moist substrate was then sterilized at $121^{\circ} \mathrm{C}$ for $30 \mathrm{~min}$. After autoclaving, $4.0 \%$ methanol were added to the medium. A concentration of $10^{7}$ spores per gram of substrate was also added, and the $\mathrm{SSC}$ was carried out, at $30^{\circ} \mathrm{C}$, for seven days. After the cultivation period, the sample was homogenized for the extraction of organic acids by adding 1:15 (w/v) of distilled water, at $200 \mathrm{rpm}$ agitation, at $30^{\circ} \mathrm{C}$, for
$30 \mathrm{~min}$. The resulting material was vacuum-filtered and centrifuged for $20 \mathrm{~min}$ at $8,000 \mathrm{rpm}$ and $4^{\circ} \mathrm{C}$. All experiments were carried out in triplicate, and the data were calculated as means \pm standard deviations.

The concentrations of gluconic, oxalic, and citric acids were determined by the high-performance liquid chromatography (HPLC) system of Waters Corporation (Milford, MA, USA), which consisted of: W515 HPLC pumps, W717 injector, and W486 UV reader, besides the Aminex HPX-87H column (Bio-Rad, Hercules, CA, USA) and $5.0 \mathrm{mmol} \mathrm{L}^{-1}$ sulfuric acid solution as the mobile phase, at a flow rate of $0.6 \mathrm{~mL} \mathrm{~min}^{-1}$ with isocratic pumping. Medium $\mathrm{pH}$ was measured with a glass electrode, and titratable acidity was obtained by titrating a sample containing $10 \mathrm{~mL}$ extract acid with a $0.01 \mathrm{~mol} \mathrm{~L}^{-1} \mathrm{NaOH}$ solution, using about three drops of a solution of phenolphthalein $1.0 \mathrm{wt} \%$ as an indicator. Total reducing sugars were obtained by the 3,5-dinitrosalicylic acid method (Miller, 1959) after the samples, prepared according to Dezam et al. (2017), were neutralized. Total reducing sugars and $\mathrm{pH}$ parameters were assessed over a 144 -hour period. The soluble P content was determined by the colorimetric method adapted from Murphy \& Riley (1962).

A rotatable central composite design (RCCD) with eight runs plus five central points was used to determine the effects of the two following independent variables: sucrose and rock phosphate concentration. The investigated ranges were: $22.5-52.5$ g per kilogram of substrate for sucrose and $0.5-1.5 \mathrm{~g}$ per kilogram of substrate for rock phosphate. The response variables were: citric acid production (gram per kilogram of substrate), solubilized or soluble P (gram per kilogram of substrate), efficiency of solubilization (percentage of solubilized phosphate rock), remaining sugar (gram per kilogram of substrate), and final $\mathrm{pH}$. The statistical analysis of the RCCD was carried out using the Statistica, version 8.0, software (Statsoft Inc., Tulsa, OK, USA).

\section{Results and Discussion}

The type of sugarcane bagasse and fungal strain affected organic acid production (Figure 1). The untreated bagasse resulted in a higher organic acid production for all strains evaluated. Among the different strains, A. niger 763 and A. niger $\mathrm{C}$ showed a higher organic acid production, reaching $228 \pm 3$ and $200 \pm 3 \mathrm{~g}$ acid per kilogram of substrate, respectively. 
These values were even higher than the one found for A. niger 9142 , which is considered a reference strain for organic acid production (Xie \& West, 2009). In a previous report on SSC with endophytic fungi strains, the highest organic acid production was of $135.5 \mathrm{~g}$ per kilogram of substrate for Aspergillus awamori 09 (Dezam et al., 2017). Therefore, the organic acid production obtained in the present work can be considered interesting when compared with those of earlier studies.

The pretreatment of the lignocellulosic biomass used as a solid substrate for SSC aims to facilitate microbial access to carbohydrates (Soccol et al., 2008; Arenas-Cárdenas et al., 2017). However, the used steam-explosion pretreatment can also release some compounds, such as furan derivatives, weak acids, and phenolic compounds, which can act as inhibitors of

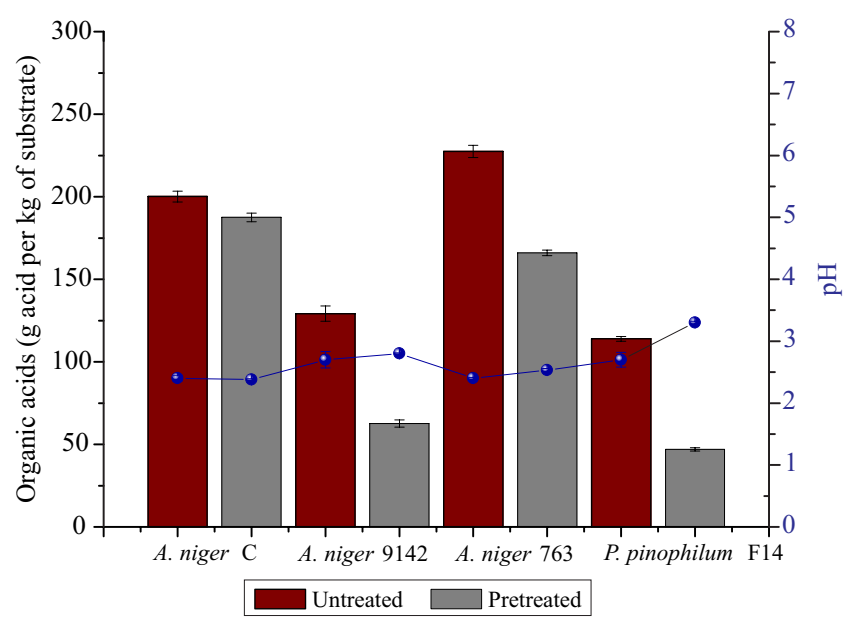

Figure 1. Effect of type of sugarcane (Saccharum officinarum) bagasse on organic acid production and $\mathrm{pH}$ variation of four different strains of filamentous fungi. $A$. niger, Aspergillus niger; and $P$. pinophilum, Penicillium pinophilum. biochemical reactions (Alvira et al., 2010; Vasconcellos et al., 2015). Phenolic compounds, for instance, are not only able to inhibit but also to deactivate the enzymes produced by microorganisms (Ximenes et al., 2010; Vasconcellos et al., 2015). Therefore, for the present study, whose objective is to improve organic acid production, the use of untreated sugarcane bagasse can be considered both technically and economically more favorable, since it avoids the pretreatment step.

Besides the concentration of organic acid being produced, the type of acid is also important for phosphate solubilization (Vassilev et al., 2006; Kubicek et al., 2011). In the present work, the most produced organic acid was citric acid, and $A$. niger $\mathrm{C}$ was the strain with the highest production of $242 \pm 2.84$ and $265 \pm 0.90 \mathrm{~g}$ citric acid per kilogram of substrate for the untreated and pretreated bagasse, respectively (Table 1). Citric acid is the most versatile, widely-used, and important acid produced by fermentation (Soccol et al., 2006). In addition, this acid's high water solubility and chelating properties due to three carboxyl groups are key characteristics in the solubilization of phosphate rock by A. niger (Xiao et al., 2013; Klaic et al., 2018).

The evaluation of the time profile for citric acid production by $A$. niger $\mathrm{C}$ (Figure $2 \mathrm{~A}$ ) showed that, under SSC using untreated sugarcane bagasse, there was a marked increase in production from 48 up to 96 hours, and, afterwards, a steady increase. According to the literature, the kinetics of acid formation is usually different from that of $A$. niger growth due to lag time, also known as maturation time (around 40 hours). This is the period during which the culture has taken up all the ammonium ions but has not yet started producing citric acid (Papagianni, 2007). The highest production of citric acid $\left(312.5 \pm 3 \mathrm{~g} \mathrm{~kg}^{-1}\right)$ was achieved after 144 hours of cultivation, leading to a medium with $\mathrm{pH}$ of 2.2 .

Table 1. Production of different organic acids by four fungal strains using untreated (UN) and pretreated (PT) sugarcane (Saccharum officinarum) bagasse as a substrate for solid-state cultivation. The values were obtained by the high-performance liquid chromatography analysis.

\begin{tabular}{|c|c|c|c|c|c|c|c|c|}
\hline \multirow{2}{*}{$\begin{array}{l}\text { Organic acid } \\
(\mathrm{g} \text { per kg of substrate })^{(1)}\end{array}$} & \multicolumn{2}{|c|}{ Aspergillus niger 9142} & \multicolumn{2}{|c|}{ Aspergillus niger $\mathrm{C}$} & \multicolumn{2}{|c|}{ Aspergillus niger 763} & \multicolumn{2}{|c|}{ Penicillium pinophilum $\mathrm{F}-14$} \\
\hline & UN & PT & UN & $\mathrm{PT}$ & UN & PT & UN & PT \\
\hline Citric & $23 \pm 0.05$ & $22 \pm 0.06$ & $242 \pm 2.84$ & $265 \pm 0.90$ & $88 \pm 1.45$ & $89 \pm 1.23$ & 0.0 & 0.0 \\
\hline Oxalic & 0.0 & $2 \pm 0.12$ & $5 \pm 0.11$ & $6 \pm 0.02$ & $5 \pm 0.07$ & $6 \pm 0.03$ & 0.0 & 0.0 \\
\hline Gluconic & $1 \pm 0.01$ & $1 \pm 0.02$ & $1 \pm 0.02$ & $1 \pm 0$ & 0.0 & 0.0 & $9 \pm 0.04$ & $4 \pm 0.05$ \\
\hline Acetic & $8 \pm 0.04$ & $4 \pm 0.07$ & $3 \pm 0.08$ & $8 \pm 0.03$ & $6 \pm 0.10$ & $8 \pm 0.06$ & $3 \pm 0.02$ & $1 \pm 0.05$ \\
\hline Formic & $2 \pm 0.02$ & 0.0 & 0.0 & 0.0 & 0.0 & 0.0 & 0.0 & 0.0 \\
\hline
\end{tabular}

${ }^{(1)}$ The lactic, succinic, tartaric, and malonic organic acids were quantified but not detected at significant concentrations. 
Regarding citric acid productivity, the most interesting value was obtained with A. niger $\mathrm{C}$ in 120 hours $-2.5 \mathrm{~g}$ citric acid per kilogram of substrate per hour or $60 \mathrm{~g}$ citric acid per kilogram of substrate per day (Figure 2 B). This productivity value is notably superior to those previously reported. The maximum citric acid productivity found by Khosravi-Darani \& Zoghi (2008) was about 22 g per kilogram per day for $A$. niger 9142 under SSC using crude sugarcane bagasse. Yu et al. (2018) observed a maximum productivity of $2.3 \mathrm{~g} \mathrm{~L}^{-1}$ per hour when using repeatedfed batch fermentation by $A$. niger immobilized on a porous foam. Therefore, the ability of strain $A$. niger $\mathrm{C}$ to produce expressive amounts of organic acids, in
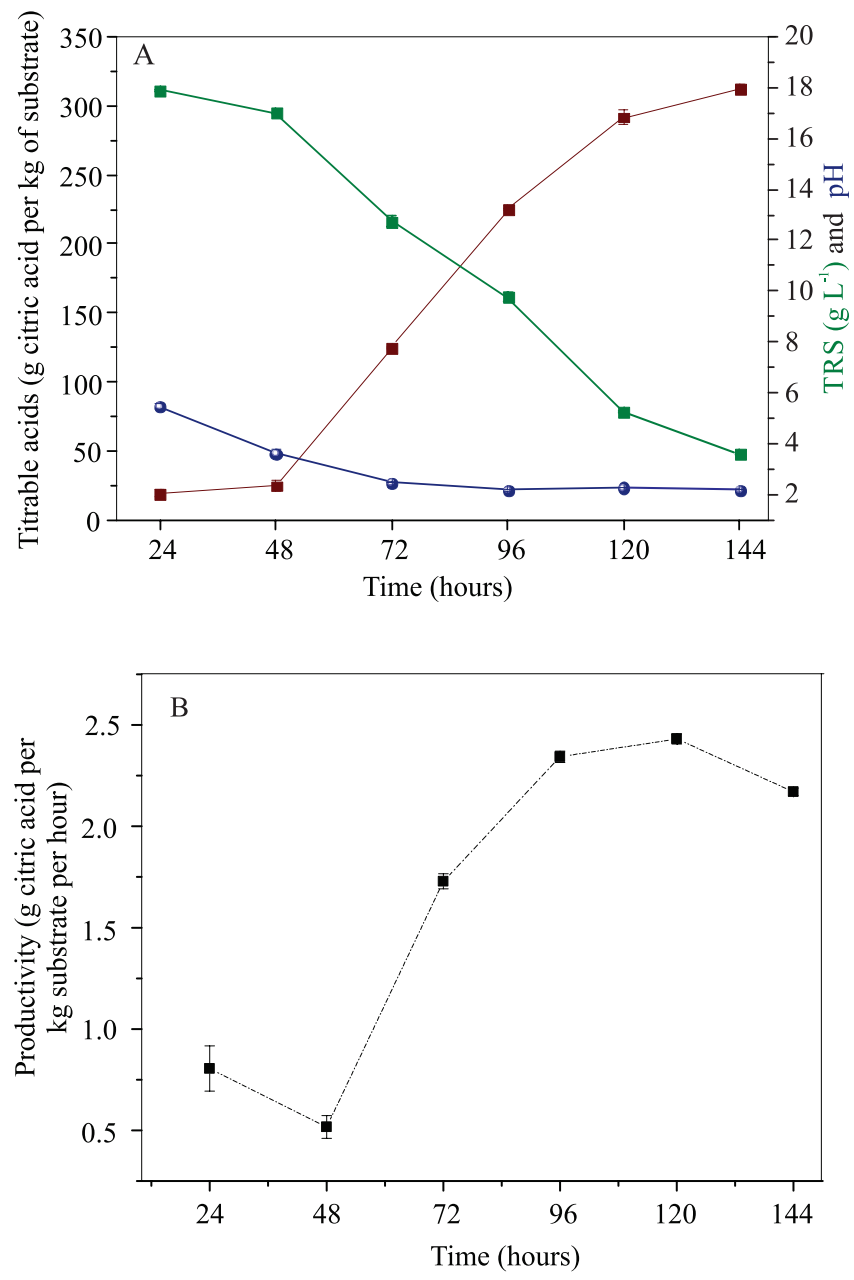

Figure 2. Time profile for citric acid production, total sugar consumed, and $\mathrm{pH}$ values during solid-state cultivation of the Aspergillus niger $\mathrm{C}$ strain using untreated sugarcane (Saccharum officinarum) bagasse as a solid substrate (A), as well as citric acid productivity (gram acid per hour) (B). particular of citric acid, under SSC using untreated sugarcane bagasse as a substrate, justifies the further investigation of this strain and of these cultivation conditions to promote the solubilization of the $\mathrm{P}$ from the IPR, an igneous rock with a very low P solubility.

Regarding the chemical analysis of the IPR (Table 2), an effective content of $20.3 \mathrm{wt} \% \quad \mathrm{P}_{2} \mathrm{O}_{5}$, which is around $8.86 \mathrm{wt} \% \mathrm{P}$, was observed. Moreover, there was a considerable amount of $\mathrm{SiO}_{2}(36.4 \mathrm{wt} \%)$, evidencing the existence of a quartz phase. A detailed characterization of the IPR carried out by Klaic et al. (2018) showed the predominance of two main phases: quartz and apatite; the latter is a type of fluorapatite $\left(\mathrm{Ca}_{5}\left(\mathrm{PO}_{4}\right)_{3} \mathrm{~F}\right)$.

The taken micrographs show the morphology of the IPR (Figure 3), which presents a smooth surface with low roughness due to the high amount of quartz in its chemical structure. A tendency to form some particle agglomerates after the mechanical activation of the IPR was also observed. The surface area of the IPR was 3.2 and $5.13 \mathrm{~m}^{2} \mathrm{~g}^{-1}$ without and with mechanical activation, respectively, which shows an increase of around $60 \%$. Regarding the particle distribution profile, particle size was below $80 \mathrm{~nm}$ with mechanical activation and above $160 \mathrm{~nm}$ without mechanical activation. Even though mechanical activation can contribute to increase the solubilization of the IPR, its crystalline phase with a high amount of quartz - characteristic of phosphate rocks of igneous origin - makes it hard and difficult to solubilize (Chien, 1993). Therefore, using an optimized microbial citric acid production

Table 2. Chemical analysis of the phosphate rock from the Itafós company, located in Arraias, in the state of Tocantins, Brazil.

\begin{tabular}{lc}
\hline Oxide species & Mass (\%) \\
\hline $\mathrm{SiO}_{2}$ & 36.40 \\
$\mathrm{Al}_{2} \mathrm{O}_{3}$ & 4.60 \\
$\mathrm{Fe}_{2} \mathrm{O}_{3}$ & 2.03 \\
$\mathrm{CaO}$ & 30.40 \\
$\mathrm{MgO}$ & 0.52 \\
$\mathrm{TiO}_{2}$ & 0.22 \\
$\mathrm{P}_{2} \mathrm{O}_{5}$ & 20.29 \\
$\mathrm{Na}_{2} \mathrm{O}$ & 0.30 \\
$\mathrm{~K}_{2} \mathrm{O}$ & 0.88 \\
$\mathrm{MnO}$ & 0.10 \\
Loss at ignition & 4.33 \\
\hline Total & 100 \\
\hline
\end{tabular}


system can be an interesting strategy to improve the solubilization of P from the IPR.

In order to evaluate the integration of the IPR in the citric acid production system being studied, the RCCD was used, varying the concentration of the carbon source (sucrose) and the amount of the IPR in the SSC of $A$. niger with sugarcane bagasse. Table 3 summarizes the conditions of the SSC and the results for the dependent response variables citric acid, solubilized $\mathrm{P}$,
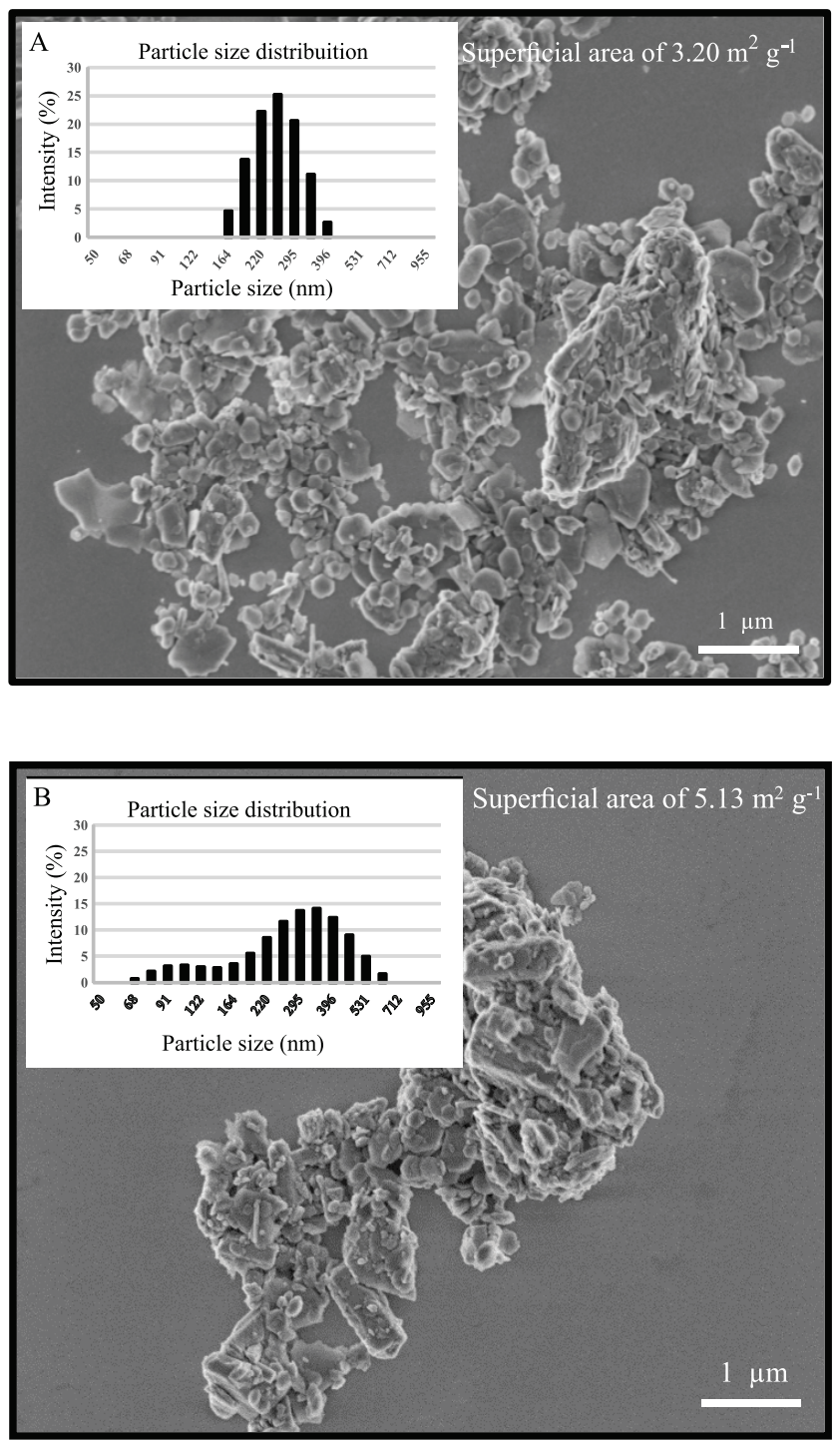

Figure 3. Micrographs and particle size distribution obtained by field emission gun scanning electron microscopy (FEG-SEM) - of phosphate rock from the Itafós company, located in Arraias, in the state of Tocantins, Brazil, without (A) and with (B) mechanical activation. phosphate rock solubilization yield (\%), residual sugar, and final $\mathrm{pH}$. The amount of citric acid produced varied from 68.06 to $118.85 \mathrm{~g}$ per kilogram of substrate in runs 8 and 10, respectively. These values are lower than that of $300 \mathrm{~g}$ per kilogram of substrate achieved without the addition of the IPR. However, the residual sugar in the system, ranging from 11.81 to $35.62 \mathrm{~g}$ per kilogram of substrate in runs 8 and 6 , respectively, was higher than that in the experiments without the IPR. These data show that there was a lower conversion of sucrose into citric acid, compared with the condition without the IPR, with a residual sugar of $4.0 \mathrm{~g}$ per kilogram of substrate. A possible explanation for this result is related to the presence of $\mathrm{Fe}$ and $\mathrm{Al}$ in the IPR (Table 2), since even low concentrations of these elements in the cultivation medium can negatively affect the production of citric acid (Klaic et al., 2018). Despite the lower citric acid production, the final $\mathrm{pH}$ was similar to the one of the cultivation without the IPR, ranging from 2.7 to 2.9. These SSC conditions resulted in solubilized $\mathrm{P}$ values from 1.44 to $2.72 \mathrm{~g}$ per kilogram of substrate in runs 7 and 8 , respectively, and in a solubilization yield of phosphate rock from 12.96 to $48.94 \%$ in runs 1 and 7 .

The statistical analysis showed that, for citric acid production, both independent variables - sucrose and IPR concentration - were statistically significant, since the p-values were smaller than 0.05 for each. Furthermore, there were significant second-order interactions between the independent variables.

The statistical analysis also enabled the definition of models to describe the observed effects on the response variables citric acid production, solubilized $\mathrm{P}$, and solubilized phosphate rock, as well as to generate the contour plots shown in Figure $4 \mathrm{~A}-\mathrm{C}$, respectively.

The model defined to estimate citric acid production in terms of the concentrations of sucrose (SC) and IPR is described by the following equation:

Citric acid production $=74.20+1.25 \mathrm{SC}-0.03 \mathrm{SC}^{2}+$ 5.77IPR - 0.57 $\mathrm{IPR}^{2}+0.11 \mathrm{SC} \times \mathrm{IPR}$

The model was validated by the analysis of variance (Anova), with a calculated F-test about 23 times the tabulated one for $5 \%$ probability and a coefficient of determination $\left(\mathrm{R}^{2}\right)$ of 0.71 .

Regarding the amount of solubilized $\mathrm{P}$, the statistical analysis showed that only the IPR concentration was significant $(\mathrm{p}<0.05)$, presenting a linear and quadratic effect, as described by the following equation: 
Solubilized $\mathrm{P}=1.85-0.11 \mathrm{IPR}+0.0086 \mathrm{IPR}^{2}$

In this case, the model was also validated by the Anova, with a calculated F-test about 11 times the tabulated one for $5 \%$ probability and a $\mathrm{R}^{2}$ of 0.82 .

A similar effect was found for the solubilization yield of phosphate rock (percentage of solubilized phosphate rock), as only the IPR concentration was significant ( $p$ $<0.05$ ), also presenting a linear and quadratic effect, as described by the following equation:

Solubilized phosphate rock $(\%)=68.19-8.35 \mathrm{IPR}+$ $0.31 \mathrm{IPR}^{2}$

The defined model was validated by the Anova, with a calculated F-test about 100 times the tabulated one for $5 \%$ probability and a $\mathrm{R}^{2}$ of 0.98 .

The results showed an optimal range for citric acid production between $20-45 \mathrm{~g}$ sucrose per kilogram of substrate and between 5-10 g IPR per kilogram of substrate (Figure 4 A). However, when the solubilization of phosphate rock was analyzed, two distinct responses were observed for the amount of solubilized $\mathrm{P}$ and the solubilization yield of phosphate rock. The solubilization yield was higher for lower IPR concentrations, whereas the amount of solubilized $\mathrm{P}$ (available P or soluble P) was higher for higher IPR concentrations in the culture medium.

The potential of organic acids to promote the solubilization of phosphate rock is determined by their ability to chelate cations (mainly calcium) bound to phosphate (Kpomblekou-a \& Tabatabai, 1994; Illmer \&
Schinner, 1995; Mendes et al., 2014; Lazo et al., 2017). Therefore, the negative correlation between the amount of solubilized $\mathrm{P}$ and the solubilization yield of the $\mathrm{P}$ from the IPR might be explained by the insufficient citric acid production to promote the solubilization of all the added IPR. Another possible explanation is the limited contact of the IPR particle with the citric acid produced during microbial cultivation, due to the low diffusion rates of the citric acid in the solid-culture medium.

Among the obtained values, the one of $2.72 \mathrm{~g}$ solubilized $\mathrm{P}$ per kilogram of substrate in run 8 can be considered interesting when compared with those of previous studies. Vassilev et al. (2007) found a concentration of $2.06 \mathrm{~g}$ solubilized $\mathrm{P}$ per kilogram of substrate, whereas Mendes et al. (2013) reported a concentration of up to $259 \mathrm{mg} \mathrm{L}^{-1}$ solubilized $\mathrm{P}$ (equivalent to $2.59 \mathrm{~g}$ solubilized $\mathrm{P}$ per kilogram of substrate) when cultivating $A$. niger in solid state using a similar rock phosphate concentration. However, both studies used a rock from Morocco, of sedimentary origin, and with a high solubilization, with $12 \%$ $\mathrm{P}_{2} \mathrm{O}_{5}$, differently from that used in the present study, which is from Brazil, of igneous origin, and with a low solubilization, with $8.6 \% \mathrm{P}_{2} \mathrm{O}_{5}$. This makes the current findings even more motivating, since there is a greater solubilization with a rock of less favorable solubilization.

Table 3. Matrix of the rotatable central composite design used to evaluate the influence of sucrose and rock phosphate concentrations on citric acid production and phosphate rock solubilization.

\begin{tabular}{|c|c|c|c|c|c|c|c|c|}
\hline \multirow[t]{2}{*}{ Run } & \multicolumn{2}{|c|}{ Independent variable } & \multicolumn{6}{|c|}{ Dependent variable } \\
\hline & $\begin{array}{c}\text { Sucrose } \\
\text { (g per kg of } \\
\text { substrate) }\end{array}$ & $\begin{array}{c}\text { Phosphate rock } \\
\text { (g per kg of } \\
\text { substrate) }\end{array}$ & $\begin{array}{c}\text { Solubilized } \mathrm{P} \\
\text { ( } \mathrm{g} \text { of soluble } \mathrm{P} \text { per } \mathrm{kg} \\
\text { of substrate) }\end{array}$ & $\begin{array}{c}\text { Solubilized } \\
\text { phosphate rock } \\
(\%)\end{array}$ & $\begin{array}{l}\text { Citric acid } \\
\text { (g per kg of } \\
\text { substrate) }\end{array}$ & $\begin{array}{c}\text { Residual sugar } \\
\text { (g per kg of } \\
\text { substrate) }\end{array}$ & $\begin{array}{c}\text { Final } \\
\mathrm{pH}\end{array}$ & $\begin{array}{c}\text { Solubilized } \\
\mathrm{P} / \text { sucrose }\end{array}$ \\
\hline 1 & $22.5(-1)$ & $15(1)$ & 1.94 & 12.96 & 84.19 & 34.90 & 2.86 & 8.64 \\
\hline 2 & $52.5(1)$ & $5(-1)$ & 1.63 & 32.60 & 77.09 & 14.71 & 2.88 & 3.10 \\
\hline 3 & $22.5(-1)$ & $5(-1)$ & 1.57 & 31.31 & 97.44 & 31.79 & 2.85 & 6.96 \\
\hline 4 & $52.5(1)$ & $15(1)$ & 1.85 & 12.34 & 97.25 & 15.08 & 2.85 & 3.53 \\
\hline 5 & $16.35(-1.41)$ & $10(0)$ & 1.68 & 16.77 & 109.54 & 25.56 & 2.88 & 10.26 \\
\hline 6 & $58.65(1.41)$ & $10(0)$ & 1.56 & 15.59 & 104.74 & 35.62 & 2.78 & 2.66 \\
\hline 7 & $37.5(0)$ & $2.95(-1.41)$ & 1.44 & 48.94 & 118.46 & 33.62 & 2.75 & 3.85 \\
\hline 8 & $37.5(0)$ & $17.05(1.41)$ & 2.72 & 15.95 & 68.06 & 11.81 & 2.88 & 7.25 \\
\hline 9 & $37.5(0)$ & $10(0)$ & 1.64 & 16.43 & 114.82 & 30.41 & 2.82 & 4.38 \\
\hline 10 & $37.5(0)$ & $10(0)$ & 1.63 & 16.32 & 118.85 & 29.40 & 2.79 & 4.35 \\
\hline 11 & $37.5(0)$ & $10(0)$ & 1.61 & 16.13 & 117.31 & 31.61 & 2.82 & 4.30 \\
\hline 12 & $37.5(0)$ & $10(0)$ & 1.62 & 16.27 & 116.44 & 30.19 & 2.85 & 4.31 \\
\hline 13 & $37.5(0)$ & $10(0)$ & 1.52 & 15.24 & 114.62 & 28.62 & 2.84 & 4.32 \\
\hline
\end{tabular}



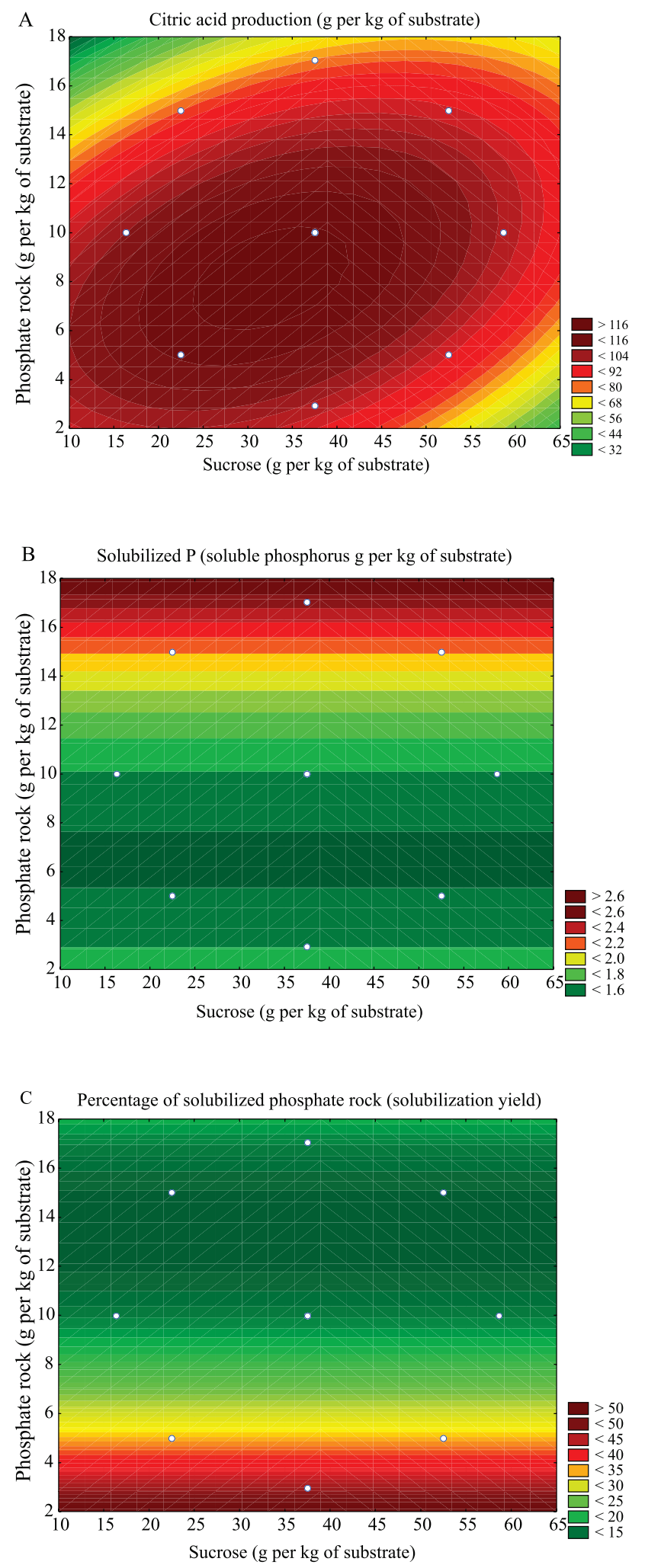

Figure 4. Contour plots showing the influence of the sucrose and rock phosphate concentrations on citric acid production (A), solubilized phosphorous (B), and yield of $\mathrm{P}$ solubilization (C).
A significant relationship was observed between the carbon source supplementation (concentration of sucrose) and amount of solubilized P (Table 3). The best results were 10.26 for the solubilized $\mathrm{P} /$ sucrose ratio and $1.68 \mathrm{~g}$ per kilogram of substrate for solubilized $P$, both in run 5 . Although the latter value is $38 \%$ lower than that of the P solubilized in run 8 , it allows an economy in sucrose supplementation of $56 \%$ and a production of citric acid $60 \%$ higher. This finding can be considered of great importance, as it could contribute to reduce the costs of the biofertilizer production process.

\section{Conclusions}

1. The solubilization by Aspergillus niger of the phosphorus from an igneous phosphate rock from the Itafós company (IPR) can be significantly improved by adjusting the conditions of solid-state cultivation in sugarcane (Saccharum officinarum) bagasse.

2. The concentrations of carbon source and IPR play an important role in citric acid production efficiency and amount of solubilized $P$.

3. Favorable conditions for solubilized $\mathrm{P}$ and citric acid production could be achieved by the analysis of the solubilized $\mathrm{P} /$ sucrose ratio, with an economy in sucrose supplementation and improvement in the production of citric acid.

4. The obtained P-solubilization values are promising, considering that the IPR is an igneous rock of very low solubilization, obtained from Arraias, in the state of Tocantins, Brazil.

\section{Acknowledgments}

To Fundação de Amparo à Pesquisa do Estado de São Paulo (Fapesp, grant number 2016/10636-8), to Conselho Nacional de Desenvolvimento Científico e Tecnológico (CNPq, grant number 2014/142348-7), and to Coordenação de Aperfeiçoamento de Pessoal de Nível Superior (Capes), for financial support; and to AgroNano Network from Embrapa Research Network and to Embrapa Instrumentação, for institutional support.

\section{References}

ALVIRA, P.; TOMÁS-PEJÓ, E.; BALLESTEROS, M.; NEGRO, M.J. Pretreatment technologies for an efficient bioethanol 
production process based on enzymatic hydrolysis: a review. Bioresource Technology, v.101, p.4851-4861, 2010. DOI: https://doi.org/10.1016/j.biortech.2009.11.093.

ARENAS-CÁRDENAS, P.; LÓPEZ-LÓPEZ, A.; MOELLERCHÁVEZ, G.E.; LEÓN-BECERRIL, E. Current pretreatments of lignocellulosic residues in the production of bioethanol. Waste and Biomass Valorization, v.8, p.161-181, 2017. DOI: https://oi.org/10.1007/s12649-016-9559-4.

BENICIO, L.P.F.; CONSTANTINO, V.R.L.; PINTO, F.G.; VERGÜTZ, L.; TRONTO, J.; COSTA, L.M. da. Layered double hydroxides: new technology in phosphate fertilizers based on nanostructured materials. ACS Sustainable Chemistry \& Engineering, v.5, p.399-409, 2017. DOI: https://doi.org/10.1021/ acssuschemeng.6b01784.

CHIEN, S.H. Solubility assessment for fertilizer containing phosphate rock. Fertilizer Research, v.35, p.93-99, 1993. DOI: https://doi.org/10.1007/bf00750223.

DEZAM, A.P.G.; VASCONCELLOS, V.M.; LACAVA, P.T.; FARINAS, C.S. Microbial production of organic acids by endophytic fungi. Biocatalysis and Agricultural Biotechnology, v.11, p.282-287, 2017. DOI: https://doi.org/10.1016/j. bcab.2017.08.001.

EVERAERT, M.; WARRINNIER, R.; BAKEN, S.; GUSTAFSSON, J.-P.; DE VOS, D.; SMOLDERS, E. Phosphateexchanged Mg-Al layered double hydroxides: a new slow release phosphate fertilizer. ACS Sustainable Chemistry \& Engineering, v.4, p.4280-4287, 2016. DOI: https://doi.org/10.1021/ acssuschemeng.6b00778.

FARINAS, C.S. Developments in solid-state fermentation for the production of biomass-degrading enzymes for the bioenergy sector. Renewable \& Sustainable Energy Reviews, v.52, p.179188, 2015. DOI: https://doi.org/10.1016/j.rser.2015.07.092.

ILLMER, P.; SCHINNER, F. Solubilization of inorganic calcium phosphates - solubilization mechanisms. Soil Biology and Biochemistry, v.27, p.257-263, 1995. DOI: https://doi.org/10.1016/0038-0717(94)00190-C.

KHOSRAVI-DARANI, K.; ZOGHI, A. Comparison of pretreatment strategies of sugarcane baggase: experimental design for citric acid production. Bioresource Technology, v.99, p.69866993, 2008. DOI: https://doi.org/10.1016/j.biortech.2008.01.024.

KLAIC, R.; PLOTEGHER, F.; RIBEIRO, C.; ZANGIROLAMI, T.C.; FARINAS, C.S. A fed-batch strategy integrated with mechanical activation improves the solubilization of phosphate rock by Aspergillus niger. ACS Sustainable Chemistry \& Engineering, v.6, p.11326-11334, 2018. DOI: https://doi.org/10.1021/acssuschemeng.8b00885.

KLAIC, R.; PLOTEGHER, F.; RIBEIRO, C.; ZANGIROLAMI, T.C.; FARINAS, C.S. A novel combined mechanical-biological approach to improve rock phosphate solubilization. International Journal of Mineral Processing, v.161, p.50-58, 2017. DOI: https://doi.org/10.1016/j.minpro.2017.02.009.

KPOMBLEKOU-A, K.; TABATABAI, M.A. Effect of organic acids on release of phosphorus from phosphate rocks. Soil Science, v.158, p.442-453, 1994. DOI: https://doi.org/10.1097/00010694199415860-00006.
KUBICEK, C.P.; PUNT, P.; VISSER, J. Production of organic acids by filamentous fungi. In: HOFRICHTER, M. (Ed.). Industrial applications. $2^{\text {nd }}$ ed. Berlin: Springer-Verlag, 2011. p.215-234. DOI: https://doi.org/10.1007/978-3-642-11458-8_10.

KUMAR, D.; JAIN, V.K.; SHANKER, G.; SRIVASTAVA, A. Citric acid production by solid state fermentation using sugarcane bagasse. Process Biochemistry, v.38, p.1731-1738, 2003. DOI: https://doi.org/10.1016/s0032-9592(02)00252-2.

LAZO, D.E.; DYER, L.G.; ALORRO, R.D. Silicate, phosphate and carbonate mineral dissolution behaviour in the presence of organic acids: a review. Minerals Engineering, v.100, p.115-123, 2017. DOI: https://doi.org/10.1016/j.mineng.2016.10.013.

LI, Z.; BAI, T.; DAI, L.; WANG, F.; TAO, J.; MENG, S.; HU, Y.; WANG, S.; HU, S. A study of organic acid production in contrasts between two phosphate solubilizing fungi: Penicillium oxalicum and Aspergillus niger. Scientific Reports, v.6, art.25313, 2016. DOI: https://doi.org/10.1038/srep25313.

LIU, Y.H.; FENG, L.; HU, H.Q.; JIANG, G.J.; CAI, Z.J.; DENG, Y.J. Phosphorus release from low-grade rock phosphates by low molecular weight organic acids. Journal of Food, Agriculture \& Environment, v.10, p.1001-1007, 2012.

MENDES, G. de O.; FREITAS, A.L.M. de; PEREIRA, O.L.; SILVA, I.R. da; VASSILEV, N.B.; COSTA, M.D. Mechanisms of phosphate solubilization by fungal isolates when exposed to different P sources. Annals of Microbiology, v.64, p.239-249, 2014. DOI: https://doi.org/10.1007/s13213-013-0656-3.

MENDES, G. de O.; SILVA, N.M.R.M. da; ANASTÁCIO, T.C.; VASSILEV, N.B.; RIBEIRO JR., J.I.; SILVA, I.R. da; COSTA, M.D. Optimization of Aspergillus niger rock phosphate solubilization in solid-state fermentation and use of the resulting product as a P fertilizer. Microbial Biotechnology, v.8, p.930939, 2015. DOI: https://doi.org/10.1111/1751-7915.12289.

MENDES, G.O.; DIAS, C.S.; SILVA, I.R.; RIBEIRO JÚNIOR, J.I.; PEREIRA, O.L.; COSTA, M.D. Fungal rock phosphate solubilization using sugarcane bagasse. World Journal of Microbiology \& Biotechnology, v.29, p.43-50, 2013. DOI: https://doi.org/10.1007/s11274-012-1156-5.

MILLER, G.L. Use of dinitrosalicylic acid reagent for determination of reducing sugar. Analytical Chemistry, v.31, p.426-428, 1959. DOI: https://doi.org/10.1021/ac60147a030.

MURPHY, J.; RILEY, J.P. A modified single solution method for the determination of phosphate in natural waters. Analytica Chimica Acta, v.27, p.31-36, 1962. DOI: https://doi.org/10.1016/ S0003-2670(00)88444-5.

PAPAGIANNI, M. Advances in citric acid fermentation by Aspergillus niger: biochemical aspects, membrane transport and modeling. Biotechnology Advances, v.25, p.244-263, 2007. DOI: https://doi.org/10.1016/j.biotechadv.2007.01.002.

PLOTEGHER, F.; RIBEIRO, C. Characterization of single superphosphate powders - a study of milling effects on solubilization kinetics. Materials Research, v.19, p.98-105, 2016. DOI: https://doi.org/10.1590/1980-5373-mr-2015-0401.

RODRÍGUEZ-ZÚÑIGA, U.F.; FARINAS, C.S.; BERTUCCI NETO, V.; COURI, S.; CRESTANA, S. Produção de celulases 
por Aspergillus niger por fermentação em estado sólido. Pesquisa Agropecuária Brasileira, v.46, p.912-919, 2011. DOI: https://doi.org/10.1590/S0100-204X2011000800018.

SCHNEIDER, K.D.; VAN STRAATEN, P.; MIERA DE ORDUÑA, R.; GLASAUER, S.; TREVORS, J.; FALLOW, D., SMITH, P.S. Comparing phosphorus mobilization strategies using Aspergillus niger for the mineral dissolution of three phosphate rocks. Journal of Applied Microbiology, v.108, p.366-374, 2010. DOI: https://doi.org/10.1111/j.1365-2672.2009.04489.x.

SHARAN, A.; CHARAN, A.A.; BIND, A.; TIWARI, S.B. Citric acid production from pre-treated sugarcane bagasse by Aspergillus niger under solid state fermentation. Asian Journal of Bio Science, v.10, p.162-166, 2015. DOI: https://doi.org/10.15740/ HAS/AJBS/10.2/162-166.

SOCCOL, C.R.; VANDENBERGHE, L.P.S.; RODRIGUES, C.; MEDEIROS, A.B.P.; LARROCHE, C.; PANDEY, A. Production of organic acids by solid-state fermentation. In: PANDEY, A.; SOCCOL, C.R.; LARROCHE, C. (Ed.). Current developments in solid-state fermentation. New Delhi: Springer, 2008. p.205229. DOI: https://doi.org/10.1007/978-0-387-75213-6_10.

SOCCOL, C.R.; VANDENBERGHE, L.P.S.; RODRIGUES, C.; PANDEY, A. New perspectives for citric acid production and application. Food Technology and Biotechnology, v.44, p.141149, 2006.

VASCONCELLOS, V.M.; TARDIOLI, P.W.; GIORDANO, R.L.C.; FARINAS, C.S. Production efficiency versus thermostability of (hemi)cellulolytic enzymatic cocktails from different cultivation systems. Process Biochemistry, v.50, p.1701-1709, 2015. DOI: https://doi.org/10.1016/j.procbio.2015.07.011.

VASSILEV, N.; VASSILEVA, M.; BRAVO, V.; FERNÁNDEZSERRANO, M.; NIKOLAEVA, I. Simultaneous phytase production and rock phosphate solubilization by Aspergillus niger grown on dry olive wastes. Industrial Crops and
Products, v.26, p.332-336, 2007. DOI: https://doi.org/10.1016/j. indcrop.2007.04.003.

VASSILEV, N.; VASSILEVA, M.; NIKOLAEVA, I. Simultaneous P-solubilizing and biocontrol activity of microorganisms: potentials and future trends. Applied Microbiology and Biotechnology, v.71, p.137-144, 2006. DOI: https://doi.org/10.1007/ s00253-006-0380-z.

VASSILEVA, M.; SERRANO, M.; BRAVO, V.; JURADO, E.; NIKOLAEVA, I.; MARTOS, V.; VASSILEV, N. Multifunctional properties of phosphate-solubilizing microorganisms grown on agro-industrial wastes in fermentation and soil conditions. Applied Microbiology and Biotechnology, v.85, p.1287-1299, 2010. DOI: https://doi.org/10.1007/s00253-009-2366-0.

XIAO, C.; ZHANG, H.; FANG, Y.; CHI, R. Evaluation for rock phosphate solubilization in fermentation and soil-plant system using a stress-tolerant phosphate-solubilizing Aspergillus niger $\mathrm{WHAK}_{1}$. Applied Biochemistry and Biotechnology, v.169, p.123-133, 2013. DOI: https://doi.org/10.1007/s12010-012-9967-2.

XIE, G.; WEST, T.P. Citric acid production by Aspergillus niger ATCC 9142 from a treated ethanol fermentation co-product using solid-state fermentation. Letters in Applied Microbiology, v.48, p.639-644, 2009. DOI: https://doi.org/10.1111/j.1472765X.2009.02586.x.

XIMENES, E.; KIM, Y.; MOSIER, N.; DIEN, B.; LADISCH, M. Inhibition of cellulases by phenols. Enzyme and Microbial Technology, v.46, p.170-176, 2010. DOI: https://doi.org/10.1016/j. enzmictec.2009.11.001.

YU, B.; ZHANG, X.; SUN, W.; XI, X.; ZHAO, N.; HUANG, Z.; YING, Z.; LIU, L.; LIU, D.; NIU, H.; WU, J.; ZHUANG, W.; ZHU, C.; CHEN, Y.; YING, H. Continuous citric acid production in repeated-fed batch fermentation by Aspergillus niger immobilized on a new porous foam. Journal of Biotechnology, v.276-277, p.19, 2018. DOI: https://doi.org/10.1016/j.jbiotec.2018.03.015. 